OrinL REEIONAL STUDIES PROCRAM

An Economic Impact Analysis of Energy Facilities with Particular Reference to the Hartsville, Tennessee, Area 


\section{DISCLAIMER}

This report was prepared as an account of work sponsored by an agency of the United States Government. Neither the United States Government nor any agency Thereof, nor any of their employees, makes any warranty, express or implied, or assumes any legal liability or responsibility for the accuracy, completeness, or usefulness of any information, apparatus, product, or process disclosed, or represents that its use would not infringe privately owned rights. Reference herein to any specific commercial product, process, or service by trade name, trademark, manufacturer, or otherwise does not necessarily constitute or imply its endorsement, recommendation, or favoring by the United States Government or any agency thereof. The views and opinions of authors expressed herein do not necessarily state or reflect those of the United States Government or any agency thereof. 


\section{DISCLAIMER}

Portions of this document may be illegible in electronic image products. Images are produced from the best available original document. 
Printed in the United States of America. Available from National Technical Information Service

U.S. Department of Commerce

5285 Port Royal Road, Springfield, Virginia 22161

Price: Printed Copy $\$ 4.50$; Microfiche $\$ 3.00$

This report was prepared as an account of work sponsored by an agency of the United States Government. Neither the United States Government nor any agency thereof, nor any of their employees, contractors, subcontractors, or their employees, makes any warranty, express or implied, nor assumes any legal liability or responsibility for any third party's use or the results of such use of any information, apparatus, product or process disclosed in this report, nor represents that its use by such third party would not infringe privately owned rights. 
Contract No. W-7405-eng-26

Energy Division

\title{
AN ECONOMIC IMPACT ANALYSIS OF ENERGY FACILITIES WITH PARTICULAR REFERENCE TO THE HARTSVILLE, TENNESSEE, AREA
}

\author{
Walter Isard* \\ Thomas A. Reiner* \\ Roger Van Zele* \\ *Peace Science Department, University of Pennsylvania, \\ Philadelphia, Pennsylvania
}

Date Published: May 1979

NOTICE This document contains information of a preliminary nature. It is subject to revision or correction and therefore does not represent a final report.

Subcontract No. 7181

Prepared by the OAK RIDGE NATIONAL LABORATORY

Oak Ridge, Tennessee 37830 operated by

UNION CARBIDE CORPORATION

for the

DEPARTMENT OF ENERGY

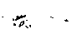

This report was prepared as an account of work sponsored by the United States Govemment. Neither the United States nor the United States Department of Eneitzy, nor any of their employees, nor any of their contractors, subcontractors, or their employees, makes any warranty, express or implies, or assusises any legal liability or responsibility for the accuracy, completeness or usefulness of any in formation, apparatus, product or process disclosed, or represents that its use would not infringe privately owned rights. 
THIS PAGE

WAS INTENTIONALLY

LEFT BLANK 


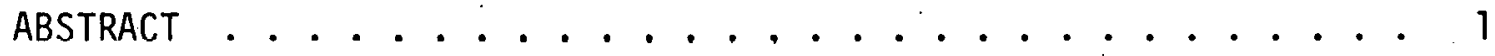

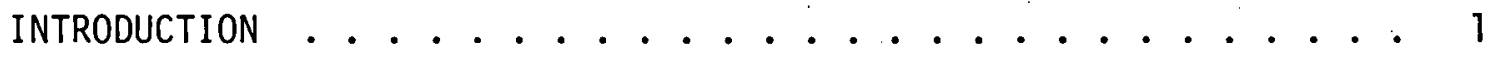

ANALYSIS OF REGIONAL ECONOMIC IMPACT ............. 3

Material Inputs . . . . . . . . . . . . . 6

Labor Inputs ................. 8

Indirect and Induced Effects ................ 12

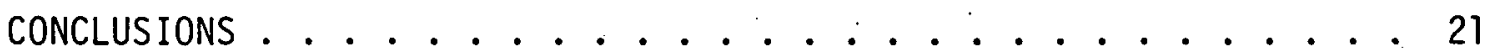

Append $1 \times$ A - SUMMARY OF OTHER FINDINGS .......... 23

Appendix B - CALCULATION OF LOCAL PURCHASES FOR A NUCLEAR PLANT

IN THE PHILADELPHIA REGION . . . . . . . . 25

BIBLIOGRAPHY .................. 33
\end{abstract}


AN ECONOMIC IMPACT ANALYSIS OF ENERGY FACILITIES WITH

PART ICULAR REFERENCE TO THE HARTSVILLE, TENNESSEE, AREA

Walter Isard Thomas A. Reiner Roger Van Zele

ABSTRACT

This study focuses on the economic impacts of construction of the Hartsville, Tennessee, nuclear power plant. Four reactor units are now under construction. Investigated are the consequences likely to be felt in a six-county region, including the site and the city of Nashville.

We conclude that about one-seventh of the material required for the construction of the installation will come from the region, about $\$ 150$ million out of more than $\$ 1$ billion. The labor bill for construction will account for more than $\$ 300$ million over eight years; the annual wage bill for operating the plant will be more than $\$ 5$ million (in 1975 dollars). In the peak year, about 5000 workers are expected to be employed in construction; the annual operating labor force is expected to be 460 .

Regional purchases of materials will, in turn, stimulate an increase in regional economic activity; over a seven-year period, we anticipate that the approximately $\$ 150$ million will generate a total increase in regional product of over $\$ 230$ million. The construction workers' expenditures, in turn, will also stimulate local economic activity - in the peak year of construction, well over $\$ 100$ million and about 13,000 new jobs. Although these effects will have a modest impact on the economy of the larger counties (and specifically on Nashville), the construction will be of major consequence for the area immediately surrounding Hartsville.

Estimates were made by applying to the construction and operating requirements of the plant an economic "multiplier," which yields an estimate of the induced and indirect effects of the power plant.

\section{INTRODUCTION}

Explored here are some new approaches to social impact assessment; our goal is to provide a method for anticipating, measuring, analyzing, 
and managing the change caused by a major construction project. ${ }^{*}$ The empirical case used as a focus for this work is the Hartsville, Tennessee, four-reactor nuclear power plant now under construction. In our research, the impacts of such major projects are considered from several perspectives.

The first perspective, described in detail here, gives specificity to the regional economic and demographic consequences of the construction and operation of the plant. Essentially a monitoring process, the study of many types of economic and demographic impacts can be done readily and can yield valuable results. ${ }^{+}$The economic consequences of the intervention constitute one class of information, which includes both changes in the magnitude and changes in the structure of the economic system as well as important distributional issues. We have, within the limits imposed by the resources available to us,-identified and set some limits to the economic and population changes anticipated to result from the construction and operation of the Hartsville nuclear plant.

A second purely exploratory and conceptual part of this research not published here provides a framework for further study. Concurrent changes in the structure and the intensity of social- interaction are monitored and anticipated to identify quantitatively key social consequences. We study the nature of the interactions among individuals within a community, particularly as this interaction is a reflection of and dependent on the degree of community solidarity. We would assume that a rich web of ties within a community would result in much interaction and potential for change in values or attitudes, and, as a further consequence, one would anticipate an intense and effective reaction to the specific intervention. Because of its highly exploratory and tentative nature, however, it would be premature to publish this second part.

The research also focuses more narrowly on the topic of standards. Generally associated with economic and demographic changes are shifts in social structures and processes as well as modifications of values, We look at the substance of impact assessment standards and the process by which these are set as one important aspect of organizational interaction. In turn, the study of any alteration of such standards becomes a necessary part of any monitoring of the effects (social and economic, among others) of an intervention such as construction of a power plant.

\section{"Insofar as there is confidence in causal modeling (Putman 1971).}

${ }^{\dagger}$ An important distinction must be made. We note that the literature is ambiguous in the terminology used; this leads to confusion of the methods to be employed. Consider construction of a power plant. Associated with this - presumably in a causal fashion - is changed demographic structure, altered level of income in the immediate surroundings, or other consequences. Studies of the effect of such a project use the word "impact" to indicate both the construction and the socineconomic change. We suggest that the word "intervention" be used to designate the first (construction, say, of a power plant) and that "impact" refer only to the second (the effects, such as the economic and the social).

Because of its highly preliminary character the last part of the report is also not published. 


\section{ANALYSIS OF REGIONAL ECONOMIC IMPACT}

One necessary ingredient of any comprehensive socioeconomic impact analysis is an assessment of the local economic and demographic changes associated with the subject development or intervention. In this section, some of these economic and demographic changes are estimated in order to provide the empirical context for other parts of the study. Although this section is not intended to provide a new approach to such estimating, it does provide a necessary quantitative foundation on which subsequent social and economic impact assessment of the Hartsville area can be built.

The approach taken in this section is aimed at ongoing impact assessment and monitoring. Consequently, an attempt has been made to make explicit all assumptive and estimated values of parameters and variables. Thus, if the reader disagrees with an assumption or. parametric value or if later information differs from assumptions made, the analys is can be modified accordingly. This, of course, implies a responsibility on the part of the users of the information to satisfy themselves that the analysis is updated with the latest available data.

The approach used is a standard multiplier analysis, one which follows from similar studies by Isard et al. $(1975 ; 1976)$ and from methodology suggested by Stenehjem and Metzger (1976). * Stated briefly, this approach is based on the premise that income, employment, and production will be determined by the demands for the materials and labor required to construct and operate the nuclear power plant at Hartsvilie, Tennessee.

To proceed with a multiplier analysis, a precise definition of the study region is useful. The study region appropriate for our purposes, as determined by consultation with Oak. Ridge National Laboratory (ORNL) personnel, includes the following six Tennessee counties (Fig. 1):

\begin{tabular}{ll}
\multicolumn{1}{c}{ County } & \multicolumn{1}{c}{ Seat } \\
\hline Davidson & Nashville \\
Macon & Lafayette \\
Smith & Carthage \\
Sumner & Gallatin \\
Trousdale & Hartsville \\
Wilson & Lebanon
\end{tabular}

These counties were selected because early information from the site indicated that the residences of construction workers would be restricted

* The input-output approach undertaken by Isard et al. (1966) for the Philadelphia region is not appropriate for the Hartsville region because of its less complex interindustry structure. 
ORNL-DWG 78-19017

KENTUCKY
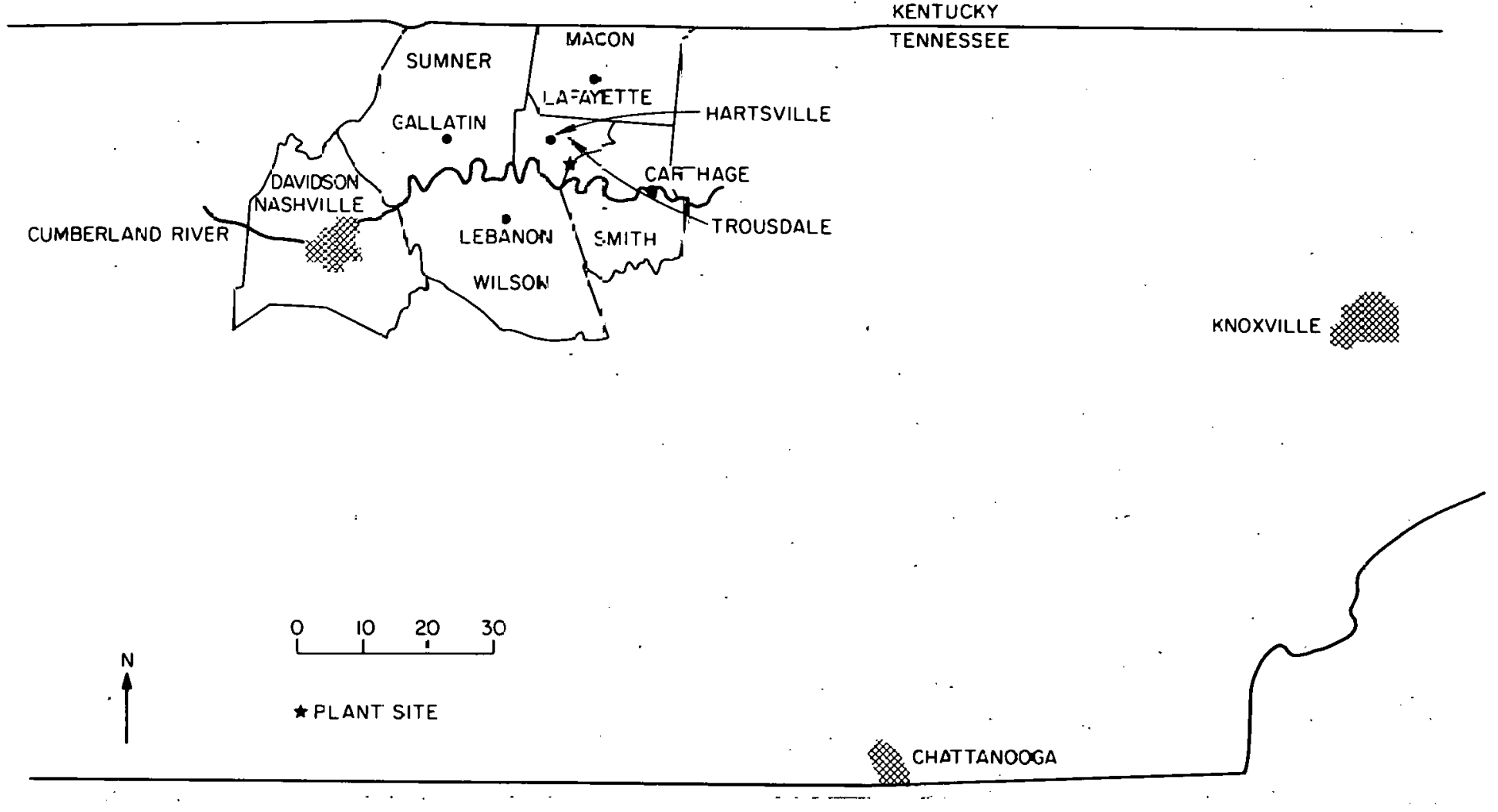

Fig. 1. Map of the six-county study region. 
largely to this area (TVA 1977). In addition, our own consideration of the economic structure of the region indicates that locally supplied goods and services necessitated by the plant (direct, indirect, and induced) will come primarily from these six counties.

This area differs slightly from the five-county study region used in earlier work by the Tennessee Valley Authority (TVA) and ORNL [e.g., the Hartsville environmental statement (NRC 1975)] by the inclusion of Davidson County. This addition was made because of the importance of metropolitan Nashville as the supply center for the region, and because through September 1976 about 25\% of the construction workers resident in the six-county region made their homes in Davidson County (TVA 1977).

The overall region is being studied instead of the component counties and localities for two reasons. First, from our brief look at the regional economic structure (e.g., supply patterns, commuting pattern), this broader region is judged to be the appropriate spatial unit through which to examine relevant economic impacts; the significant economic impacts will be felt primarily over the six designated counties. Second, the individual counties and localities were studied and are continuing to be monitored by TVA and ORNL (e.g., NRC 1975; TVA 1977; and ORNL 1977). What is missing, however, is a broader picture of the economic impact. In addition to filling out the local impact assessment, this overview can be used by others, for instance, by state or federal officials concerned with the question of equity among regions.

The following step-by-step analysis describes the elements to be considered and method to be used in our determination of economic impact:

1. The construction of a four-reactor nuclear plant at Hartsville causes a demand for certain amounts of specific materials and for direct labor of specified skills in fairly well-known quantities. Labor is $1 \mathrm{ikewise}$ required for operation and maintenance (0\&M). (Some materials are also required, but they are negligible.) Thus, as a starting point, an overall material-requirement schedule and a labor-input schedule are required. We draw an analogy between these schedules and a "recipe" for a finished plant, which might include specification by time as well as by type.

2. The material recipe can then be disaggregated into two components: those supplied locally and those imported into the region (the sixcounty study region designated above as the appropriate area). This is done by a material-supply vector that depicts the relevant proportions.

3. Next, a similar labor-supply vector is required to indicate the source of the labor needed to build the plant, that is, the region itself vs the outside area. Insofar as is possible, this information should be specified year by year.

4. Items 1 through 3 permit estimation of direct inputs to the region's economy. These inputs must then be priced using estimated material costs and wage rates. For labor inputs, one must also estimate where the wages paid are spent, both with reference to the economic sector as well as to the geographic area (i.e., within the region 
or without). For this, a consumer-demand schedule and estimated rates of leakage from the region are required.

5. Once direct impacts are estimated, indirect and induced effects on the region's economy can be calculated. For materials, this is done directly with an appropriate multiplier. A standard multiplier analysis can be undertaken for labor inputs as well.

6. Finally, the estimated economic impacts derived from the preceding steps must be translated into changes in population, employment, demand for housing and services, commuting patterns, etc., within the region. Again, certain commonly accepted factors are used.

These elements are described, in turn, in the following subsections.

\section{Material Inputs}

In Appendix B we present our estimate, from an earlier study (Isard et al: 1976), of the material inputs required to construct a 2400-MW nuclear plant in the Philadelphia region. This material-requirement schedule, which is based on U.S. Atomic Energy Commission documents and/ or consultations with engineering personnel of a New Jersey utility company, is disaggregated by four-digit Standard Industrial Classification (SIC) and by geographic source (i.e., within or without the Philadelphia region).

Using this estimate, we prepared a similar table for the Hartsville rcgion (Table 1). rirst, we deleled lhiuse llaterlals not likely to be produced within the region as determined from the Census of Manufactures (1973) and from the informed opinion of local persons. Obviously, the number and magnitude of these deletions are great because of the significant differences between the industrial bases of the Philadelphia and the Hartsville regions (the Hartsville region is basically a generously drawn Nashville region).

Our rule of thumb in making these deletions was to assume that what can be supplied locally will be supplied locally. Obviously this results in a liberal estimate of the regional effects of material purchases, but this method is preferred for two reasons. First, it is relatively unambiguous and allows the reader to modify our work easily to suit his or her own assumptions regarding supply patterns. The second reason involves the identification of certain local economic opportunitics; that is, both the local material-input schedule for the Hartsville plant, as well as the differences between the list of local material inputs for the Philadelphia region and the shorter list for the Hartsville region, may suggest certain economic opportunities for the Hartsville region. For example, 1972 production levels in the fabricated structural-metal products sectors (SIC 344) in the Hartsville region totaled about $\$ 250$ million annually, a fairly large capacity. The plant itself calls for about $\$ 100 \mathrm{million}$ worth of fabricated structural-metal products over the course of the construction period. Thus, suppliers in the Hartsville region might be in an advantageous position for supplying much of the demand given the relative magnitudes of the demand and of the existing and possible expanded capacities. 
Table 1. Material inputs for the Hartsville nuclear power plant

\begin{tabular}{|c|c|c|}
\hline SIC code & $\begin{array}{c}\text { Cos } \\
(\$ 10\end{array}$ & \\
\hline $\begin{array}{l}2421^{\circ} \\
2433 \\
2640 \\
2843 \\
2851\end{array}$ & $\begin{array}{l}0.53 \\
0.03 \\
0.13 \\
0.33 \\
0.74\end{array}$ & \\
\hline $\begin{array}{l}3251 \\
3253 \\
3271 \\
3272 \\
3273\end{array}$ & $\begin{array}{r}0.04 \\
0.01 \\
0.18 \\
0.52 \\
14.37\end{array}$ & \\
\hline $\begin{array}{l}3291 \\
3292 \\
3441 \\
3442 \\
3443\end{array}$ & $\begin{array}{r}0.01 \\
8.77 \\
29.02 \\
0.91 \\
56.03\end{array}$ & \\
\hline $\begin{array}{l}3444 \\
3449 \\
3452 \\
3496 \\
3569\end{array}$ & $\begin{array}{r}6.27 \\
13.29 \\
0.83 \\
3.03 \\
6.82\end{array}$ & \\
\hline $\begin{array}{l}3573 \\
3585 \\
3661 \\
3690 \\
7301^{b}\end{array}$ & $\begin{array}{r}5.30 \\
0.95 \\
0.12 \\
2.21 \\
10.59\end{array}$ & \\
\hline Total regional purchases & 155.03 & $(14 \%)$ \\
\hline Imported materials & 926.77 & $(86 \%)$ \\
\hline Total materials & 1081.80 & \\
\hline
\end{tabular}

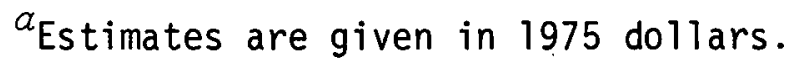

${ }^{b}$ SIC 7301 covers engineering, construction, management, and field supervision (i.e., professional services). The design work and the home office component of the construction management are being done at the Knoxville TVA offices (i.e., not with in the study region). According to WASH-1230 (USAEC 1972), these functions account for $92 \%$ of costs coded to SIC 7301 . The remaining $8 \%$ are for construction services in the field and thus are included here. 
Next, what remains on the list of local purchases has been doubled in quantity because of the size of the Hartsville plant ( $4800 \mathrm{MW}$ ) relative to the prototype Philadelphia plant (2400 MW). Our consultants at the New Jersey utility firm agree that this is appropriate because the practice of building reactors as two-unit modules means that significant economies are realized only with the addition of a second unit to a one-unit reactor. Going from two to four units, or from one to two modules, on the other hand, makes a linear extrapolation acceptable.

\section{Labor Inputs}

The environmental impact statement (EIS) for the Hartsville plant (NRC 1975) contains an estimate of construction employment which we use here as the basis for our calculations. The figures from the EIS are year-end construction force levels, but, for our purposes here, mean annual force levels are required. The estimate of the latter based on the former is presented in Table 2. Operation and maintenance (O\&M) labor requirements were drawn from Isard et al. (1976) and also appear in Table 2. Both sets of figures are roughly consistent with those of Stenehjem and Metzger (1976).

Table 2. Labor requirements for the Hartsville nuclear power plant

\begin{tabular}{|c|c|c|c|}
\hline Year & Construction $a$ & $0 \& M b$ & Total \\
\hline $\begin{array}{r}1 \\
2 \\
3 \\
4 \\
5 \\
6 \\
7 \\
8 \\
9 \\
10\end{array}$ & $\begin{array}{r}1100 \\
3200 \\
4400 \\
5100 \\
4700 \\
3400 \\
1500 \\
400 \\
0 \\
0\end{array}$ & $\begin{array}{r}0 \\
0 \\
0 \\
50 \\
250 \\
400 \\
460 \\
460 \\
460 \\
460\end{array}$ & $\begin{array}{r}1100 \\
3200 \\
4400 \\
5150 \\
4950 \\
3800 \\
1960 \\
860 \\
460 \\
460\end{array}$ \\
\hline
\end{tabular}

Next, this labor-input schedule must be disaggregated by geographic area, that is, what proportion is assumed to reside within the region initially and what share represents in-migration. An early report by TVA, with 1200 employees at the site, indicates that $14 \%$ of those employed have moved into the region (TVA 1977). This is less than the $26 \%$ projected by TVA and may reflect, as TVA suggests, the effects of local recruitment and training. We make the assumption, therefore, that 
reductions in the anticipated rates of in-migration will continue for the course of the project. In Table 3 we present the rates of in-migration anticipated in NRC 1975 and the reduced rates to be used here. To be conservative, we assumed rate reductions of $60 \%$ of the rate originally forecast rather than the $54 \%(14 / 26 \times 100)$ seen to date. The calculations of economic impact that follow reflect these rates. Should different rates be measured at a later date or be seen as more accurate, these calculations should be adjusted accordingly. Likewise, as additional data are developed, one could apply different rates to different groups; for example, separate rates could be applied to each craft or to the $0 \& M$ force.

Table 3. Percentage of in-movers in total construction force

\begin{tabular}{ccc}
\hline Year & $\begin{array}{c}\text { Predicted } \\
\text { rate }^{a}\end{array}$ & $\begin{array}{c}\text { Modified } \\
\text { rate }^{b}\end{array}$ \\
\hline 1 & 26 & 14 \\
2 & 45 & 27 \\
3 & 51 & 31 \\
4 & 54 & 32 \\
5 & 54 & 32 \\
6 & 41 & 25 \\
7 & 22 & 13 \\
8 & 22 & 13 \\
\hline
\end{tabular}

NRC 1975.

${ }^{a}$ Calculated from Table 4-1, p. D-13, of

$b_{A 11}$ at $60 \%$ of original forecast with the exception of year 1 in which actual data show that the rate was $54 \%$ of that forecast.

After determining the time profiles of labor inputs, the input of wage dollars to the region's economy can be specified. The assumptions regarding average income used in Isard et al. (1976) have not been challenged and thus appear reasonable for use here once modified to suit local conditions; that is, these average income levels were developed for the Philadelphia area and must be adjusted for the Hartsville area. Using data from a U.S. Bureau of Labor Statistics (1972) report on union wages in the construction industry, which were disaggregated by craft and weighted by the relative craft distribution for a nuclear plant project using Shurcliff's method (1977), we estimated the average income level in the Hartsville region for workers on such a project at about $75 \%$ of that for a similar project in the Philadelphia region.* This

\footnotetext{
*U.S. Bureau of Labor Statistics data used are for Philadelphia, Pa.-N.J. and for Memphis, Tenn.-Ark. Nashville data were not available.
} 
ratio is assumed to apply to 0\&M and multiplier jobs as well as to construction jobs. Because it is disposable income that finds its way into the local economy, tax rates must also be estimated to determine aftertax incomes to use in calculating economic impacts. The average income levels, assumed tax rates, and after-tax income levels for the Hartsville region used are given in Table 4.

Table 4. Average income levels and tax rates

\begin{tabular}{lccc}
\hline $\begin{array}{c}\text { Employment } \\
\text { type }\end{array}$ & $\begin{array}{c}\text { Average } \\
\text { pre-tax } \\
\text { income } \\
(\$)\end{array}$ & $\begin{array}{c}\text { Federal } \\
\text { tax rate } \\
(\% \text { of income })\end{array}$ & $\begin{array}{c}\text { Average } \\
\text { after-tax } \\
\text { income } \\
(\$)\end{array}$ \\
\hline Construction & 18,750 & 20 & 15,000 \\
0\&M & 15,000 & 20 & 12,000 \\
Multiplier jobs & 10,000 & 15 & 8,500 \\
\hline
\end{tabular}

Source: Isard et al. (1976).

The final calculation to be made to complete the picture of wagedollar inputs to the local economy includes the applications of the average after-tax annual incomes of Table 4 to the worker-year totals nf Tahle 2. First, however, some incomcs must be discounted lo accuunl for leakages from the region. That is, some workers migrating to the region for the project will probably maintain homes elsewhere and, as a |result, will send some portion of their income to dependents there. Others may send a lesser.portion of their incomes out of the region for other reasons. These flows are termed "leakages" from the region and do not affect the local economy. Estimates made by TVA indicate that approximately $35 \%$ of those workers in-migrating do so without their families; ${ }^{*}$ thus, these people can be expected to exhibit higher income leakages than do other workers. Table 5 shows the assumed leakage rates. Note that, although these individual rates are consistent with those used and justified in Isard et al. (1976), the overall effect is less than that estimated in the earlier report because of the larger transient work force estimated for the Philadelphia plant (i.e., no local recruit.ment and training efforts were considered in the earlier study).

Direct infusions of income into the regiullal economy can now be calculated. These results are shown in Table 6 on a year-by-year basis. Additional information can be developed through the use of Bureau of. Labor Statistics' estimates of family budgets. Table 7 gives an estimated budget for a family of four having a relatively high standard of living in

* Experience through late 1976 (1200 workers at site) corroborates this estimate with an actual rate of about $38 \%$ (TVA 1977). 
Table 5. Income leakage rates

\begin{tabular}{|c|c|c|}
\hline $\begin{array}{l}\text { Employment } \\
\text { type }\end{array}$ & $\begin{array}{l}\text { Leak } \\
(\% \text { of }\end{array}$ & $\begin{array}{l}\text { ge rate } \\
\text { income) }\end{array}$ \\
\hline \multicolumn{3}{|l|}{ Construction } \\
\hline Local resident & 5 & \\
\hline In-mover with family & 20 & \multirow{2}{*}{$30.5^{a}$} \\
\hline In-mover without family & 50 & \\
\hline O\&M & 5 & \\
\hline Secondary (multiplier) & 0 & \\
\hline
\end{tabular}

${ }^{\alpha}$ The $30.5 \%$ weighted average for all in-movers is based on the TVA estimate of a 65/35 split of with/wi thout families.

Table 6. Direct regional income effects from the Hartsville nuclear power plant

\begin{tabular}{ccccccc}
\hline & \multicolumn{2}{c}{ Direct employment } & & \multicolumn{2}{c}{ Income to region $\left(\$ 10^{3}\right)^{a}$} \\
\cline { 2 - 3 } \cline { 5 - 7 } Year & Construction & $0 \& M$ & & Construction & 0\&M & Total \\
\hline 1 & 1,100 & 0 & 15,086 & 0 & 15,086 \\
2 & 3,200 & 0 & 42,295 & 0 & 42,295 \\
3 & 4,400 & 0 & 57,483 & 0 & 57,483 \\
4 & 5,100 & 50 & 66,433 & 570 & 67,003 \\
5 & 4,700 & 250 & 61,222 & 2,850 & 64,072 \\
6 & 3,400 & 400 & 45,199 & 4,560 & 49,759 \\
7 & 1,500 & 460 & & 20,629 & 5,244 & 25,873 \\
8 & 400 & 460 & & 5,501 & 5,244 & 10,745 \\
9 & 0 & 460 & & 0 & 5,244 & 5,244 \\
10 & 0 & 460 & & 0 & 5,244 & 5,244 \\
\hline
\end{tabular}

${ }^{a}$ Calculated as follows:

$$
Y_{i}=I_{i j}\left[\left(1-k_{j}\right) E_{j}\right],
$$

where

$Y_{i}=$ income to region from activity $i$ ( $i=$ construction or $08 \mathrm{M}$ ), $I_{i}=$ after-tax annual income for a worker of type $i$ (Table 4),

$k_{j}=$ leakage rate for worker of type $j(j=$ local resident, inmover with family, or in-mover without family),

$E_{j}=$ number of workers of type $j$. 
Table 7. Estimated budget for a 4-person family in the Nashville, Tennessee, area, Autumn 1973

\begin{tabular}{lc}
\hline \multicolumn{1}{c}{ Budget allocation } & Percentage of total budget $(\$ 16,633)$ \\
\hline Total food & 22.24 \\
Food at home & 18.39 \\
Food away from home & 3.85 \\
Housing & 24.05 \\
Total shel ter & 17.13 \\
Furnishings and operations & 6.92 \\
Transportation & 7.79 \\
Clothing & 9.87 \\
Personal care & 2.19 \\
Medical care & 3.63 \\
Other family consumption & 7.39 \\
Other costs & 5.98 \\
Social security and disability & 3.80 \\
payments & \\
Personal income taxes & 13.06 \\
\hline
\end{tabular}

Source: U.S. Bureau of Labor Statistics (1975).

the Nashville region, a standard that can be assumed to be maintainable by the wage levels used. By applying those rates to the final column of Table 6 , one can obtain a rough estimate of the final demand for goods and services occasioned by the wages paid to construction and 0\&M workers on a year-by-year basis. Some modifications of these rates might be required to allow for the fact that a portion of the wages leaked from the region have al ready been deducted from the local direct-income effects, and the remainder might disproportionately go to one or more elements of the budget. Because the leakage rates are low, however, this adjustment is deemed unnecessary.

\section{Indirect and Induced Effects}

Given the direct effects on the study region economy, one can, through a standard multiplier analysis, estimate the total anticipated

\footnotetext{
* Given the availability of a good input-output model for the study region, the final-demand vector then could be used via the model to assess the direct and indirect effects of wages paid during the construction and O\&M stages of the plant.
} 
impact. Generally, multiplier analysis attempts to determine how change in one sector of a regional economy induces change in all sectors of that economy, either directly or indirectly. The continuous interative play of forces (or round-by-round process of interaction). leads to a series of effects in each sector, including the original one; these effects need not, though, always be in the same direction or of significant magnitude.

In this study, the initial impact on the economy results from the investment and operating expenses occasioned by the decision to build, operate, and maintain the nuclear plant at Hartsville. Wages and payments for good and services originating outside and spent locally are the moving force behind the regional expansion. In the present study, we have greatly simplified the consumption pattern of the work force and population, and only aggregate figures on impact are given. Future research might specify the precise consumption functions for households, commercial suppliers, and governments (Hirsch 1973; Isard 1960; Leven 1970). The aggregate multiplier that we employ is useful in an initial assessment of the economic impacts of a new facility in a region. Obviously, it fails to take account of price changes, imbalances in the local economic pattern, capacity constraints of the enterprises and labor force, and changes in the infrastructure of the area in responding to the projected changes in demand. In fact, the change is assumed to be absorbed rapidly; consideration is not given to a time-lag problem.

An overview of the multiplier analysis and input-output studies cited in the bibliography and other sources provides the range of multipliers. The specific multipliers used were drawn primarily from Stenehjem and Metzger (1976); the multipliers suggested for the study counties are shown in Table 8. The simple multiplier is the ratio of total employment in each county to basic employment (according to 1970 U.S. Census employment data). The complex multiplier is the same ratio with a slightly different definition of basic employment. The complex multiplier used here has been determined by estimating the number of employees whose work is not strictly basic in that it is not related to activities exported from the county and deducting this number from the basic employment figure used to compute the simple multiplier.

The complex rather than the simple multiplier is used because the estimates of construction and 0\&M labor made above include basic employment figures as defined for the complex multiplier. The simple multipler, on the other hand, would be used for any labor required outside the plant, such as that for improvements in local infrastructure (e.g., road widening or replacement housing). Such labor, we presume, would have been expended already and is a matter of record; accordingly, it is not included here.

We have not allocated the direct employment to each of the six counties of the study region. Instead, because of our interest in the regional impacts, we have chosen to apply an overall multiplier. To do this we have computed a weighted average of the individual complex multipliers from Table 8 , using the actual percentage distributions of construction-worker residences over the six counties through September 1976 (TVA 1977) as the weighting factors. This yields a composite complex multiplier for the five-county region of 2.5 . Thus, for every 1 
Table 8. Multipliers for study counties

\begin{tabular}{lcccc}
\hline & $\begin{array}{c}\text { Simple } \\
\text { multiplier }\end{array}$ & $\begin{array}{c}\text { Complex } \\
\text { multiplier }\end{array}$ & $\begin{array}{c}\text { Calculation } \\
\text { Weighting } \\
\text { factora }\end{array}$ & $\begin{array}{c}\text { composite } \\
\text { complex } \\
\text { multiplier }\end{array}$ \\
\hline Macon & 1.5 & 1.8 & 0.10 & 0.18 \\
Smith & 1.6 & 1.9 & 0.13 & 0.25 \\
Sumner & 1.9 & 2.3 & 0.06 & 0.14 \\
Trousdale & 1.5 & 1.7 & 0.30 & 0.51 \\
Wilson & 1.8 & 2.4 & 0.16 & 0.38 \\
Davidsonb & 3.0 & 4.2 & $\underline{0.25}$ & $\underline{1.05}$ \\
& & & 1.00 & 2.51 \\
\hline
\end{tabular}

$a_{\text {Based on proportion of construction workers resident in each }}$ county as of Sept. 30, 1976 (TVA 1977, Table 2).

${ }^{b}$ Davidson County (i.e., Nashville) exhibits exceptionally high multipliers relative to those commonly used in multiplier analysis. Examination of the Stenehjem and Metzger (1976) multipliers for all U.S. counties indicates that such high multipliers are common to the service-oriented urban counties of the Sun Belt. It may be that Nashville, unlike most mid-South cities, resembles the serviceoriented Sun Belt cities, and thus such high multipliers are justi= fied. Such a hypothesis should perhaps be investigated.

Source: Stenehjem and Metzger (1976).

worker-year of employment in the plant (construction and 0\&M), 1.5 additional worker-years of employment are generated within the region.

The application, in this report, of this same composite complex multiplier for 0\&M labor differs from the approach in our earlier work (Isard et al. 1976) in which a higher multiplier was used for the 0\&M labor force to reflect the less transient nature of these workers relative to the construction force. Here, however, the recruitment and training of local people for the plant vitiates this difference. An identical multiplier for both construction and 0\&M labor implies that there is no difference in the impacts generated by the two groups; this is an assumption that ought to be reviewed later from actual experience. Should such monitoring indicate significant differences, a different multiplier for 0\&M labor should be chosen and our figures modified accordingly.

Table 9 gives the total regional employment and income effects of the labor inputs to the plant. These figures include both the direct (or basic) employment and income associated with the plant (as shown in Table 6) as well as the multiplier jobs and attendant income.. Figure 2 is a profile of the regional employment and income impacts of the 
Table 9. Total regional employment and income effects of labor required for the Hartsville nuclear power plant

\begin{tabular}{|c|c|c|c|c|c|c|c|c|}
\hline \multirow[b]{2}{*}{ Year } & \multicolumn{4}{|c|}{ Employment } & \multicolumn{4}{|c|}{ Regional income $\left(\$ 10^{3}\right)^{a}$} \\
\hline & Construction & O\&M & Multiplier & Total & Construction & O\&M & Multiplier & Total \\
\hline $\begin{array}{r}1 \\
2 . \\
3 \\
4 \\
5 \\
6 \\
7 \\
8 \\
9 \\
10\end{array}$ & $\begin{array}{r}1,100 \\
3,200 \\
4,400 \\
5,100 \\
4,700 \\
3,400 \\
1,500 \\
400 \\
0 \\
0\end{array}$ & $\begin{array}{r}0 \\
0 \\
0 \\
50 \\
250 \\
400 \\
460 \\
460 \\
460 \\
460\end{array}$ & $\begin{array}{r}1,650 \\
4,800 \\
6,600 \\
7,725 \\
7,425 \\
5,700 \\
2,940 \\
1,290 \\
690 \\
690\end{array}$ & $\begin{array}{r}2,750 \\
8,000 \\
11,000 \\
12,875 \\
12,375 \\
9,500 \\
4,900 \\
2,150 \\
1,150 \\
1,150\end{array}$ & $\begin{array}{r}15,086 \\
42,295 \\
57,483 \\
66,433 \\
61,222 \\
45,199 \\
20,629 \\
5,501 \\
0 \\
0\end{array}$ & $\begin{array}{r}0 \\
0 \\
0 \\
570 \\
2,850 \\
4,560 \\
5,244 \\
5,244 \\
5,244 \\
5,244\end{array}$ & $\begin{array}{r}14,025 \\
40,800 \\
56,100 \\
65,663 \\
63,113 \\
48,450 \\
24,990 \\
10,965 \\
5,865 \\
5,865\end{array}$ & $\begin{array}{r}29,111 \\
83,095 \\
113,583 \\
132,666 \\
127,185 \\
98,209 \\
50,863 \\
21,710 \\
11,109 \\
11,109\end{array}$ \\
\hline
\end{tabular}

${ }^{a}$ Calculazed as follows:

$$
Y_{i}=I_{i} \Sigma_{j}\left[\left(1-k_{j}\right) E_{j}\right] \text {, }
$$

where

$Y_{i}=$ income to region from activity $i$ ( $i=$ construction, 0\&M, or secondary employment),

$I_{i}=$ after-tax annual income for a worker of type $i$ (see Table 4),

$k_{j}=$ leakage rate for workers of type $j(j=$ local construction worker, in-mover with family, in-mover without family, 0\&M worker, or secondary worker) (see Table 5),

$E_{j}=$ number of workers of type $j$. 


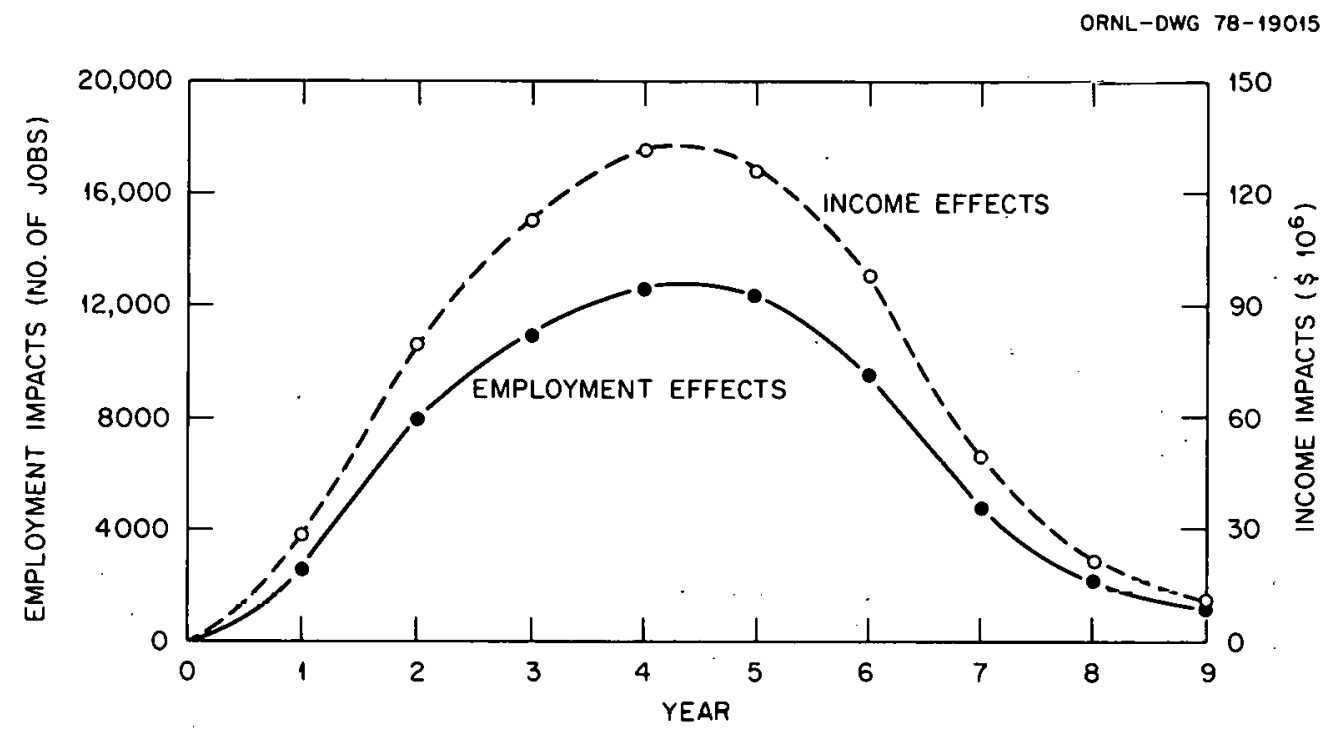

Fig. 2. Employment and income effects.

Hartsville plant. Note that an immediate generation of multiplier jobs is reflected in these figures. In reality, some time may pass between the initial payment of wages to basic employment and the appearance of the secondary employment. Accordingly, the multiplier income and employment could be "lagged" slighti.y, al though we have chosen not to do 30 here:

Another way of looking at the effects of the wages and salaries paid to the construction and 0\&M labor forces on the reginnal economy is to consider changes in the regional product. Following on with the multiplier analysis, this can be done by applying a judiciously chosen regional product multiplier to the year-by-year direct wage and salary (i.e., income) figures of Table 6 . This would yield an assessment of the increase in total regional production caused by the payment of wages and salaries. Such a calculation is essentially only a linear transformation of the final column of Table 6 and thus has not been undertaken here other than for 11 lustrative purposes. The reader should select a multiplier for the specific case under consideration, but for illustration here we have assumed a multiplier of 2.00 . The effects of wages and salaries on regional production are shown in Table 11.

A secondary category of indircct and induced effects derives from the construction and operation of the plant and includes the economic impacts occasioned by the local purchase of materials for plant construction. (We have assumed that the local materials required for $0 \& M$ are negligible.) The anticipated magnitude of these effects can also be calculated by the application of a standard multiplier to the total 
value of material purchases (Table 1 ); ${ }^{*}$ the multiplier used here is again the regional product multiplier. Should one wish to have estimates of employment impacts, they would be arrived at by calculations based on overall production impacts and a knowledge of the labor component of these changes. This is essentially the reverse of the procedure used in the multiplier analysis of labor impacts.

The choice of the regional product multiplier for the study region is open to discussion. Obviously, the multiplier must be at least 1.00 in that, by definition, the total figure from Table 1 represents local purchases. Of course, such a low multiplier would not be adequate because it implies absolutely no regional interindustry dependence. As an upper limit, consider Isard et al. (1976) in which, through detailed input-output calculations, regional product multipliers of 1.65 and 1.84 were derived for the Philadelphia region for labor and material inputs respectively. For the Hartsville plant, however, such multipliers are not likely to be achieved for at least two reasons. First, the structure of the Philadelphia economy is much more diverse and exhibits stronger regional interdependence than that of the Hartsville economy. Second, the proportion of total construction materials assumed to be supplied locally in the Philadelphia study was about $80 \%$, whereas for Hartsville the figure is only $14 \%$. From this line of reasoning and a familiarity with the literature, we chose to use a multiplier of 1.50 for our initial assessment.

A simple calculation will then indicate the sum of the direct, indirect, and induced effects of local material purchases for the construction of the Hartsville plant. Drawn from the assumed local material purchase schedule of Table 1, the equation is:

$$
\begin{aligned}
\$ 155,030,000 \times 1.50= & \$ 232,545,000 \\
{[\text { direct effect } \times \text { multiplier }=} & \text { change in regional product }(1975 \\
& \text { dol1ars })] .
\end{aligned}
$$

The increased regional product of $\$ 232.5$ million is distributed over the course of the construction project. An estimate of the form of this distribution can be made considering two factors: (1) the schedule of material procurement by which the constructors of the plant will work and

\footnotetext{
${ }^{\star}$ In Isard et al. (1976) the local material-supply schedule was used as a final-demand vector in an input-output (I-0) model to calculate detailed information on indirect and induced impacts. This was possible for little cost because of the existence of a sophisticated Philadelphia I-0 model. Such a model does not exist for the Hartsville region, al though many methods for generating rough approximations of a local I-0 matrix from national data exist. We believe, however, that the incremental worth of the result of the analysis from the construction and operation of a local I-0 model is insufficient to justify the expense of developing it. Should one become available from other sources in the near future, it would be interesting to use the figures of Tabie 1 as a final-demand vector and then to compare the result.s of such an I-0 run with the multiplier assumed here.
} 
(2) a time-lag factor that allows time for the indirect and induced effects to result from the initial stimuli of the direct effects. We originally tried to develop a material-requirement schedule through consultations with TVA but were unsuccessful in our attempts. The time-lag factor can only be applied once the schedule has been established. By way of illustration, however, we have sketched a sigmoid curve typical of procurement efforts on large construction projects to represent. the composite of the two factors (Fig. 3). Then, using this curve, we made a very rough estimate (in 1975 dollars) of the distribution over time of the total effects on the regional product of the local material purchases (Table 10).

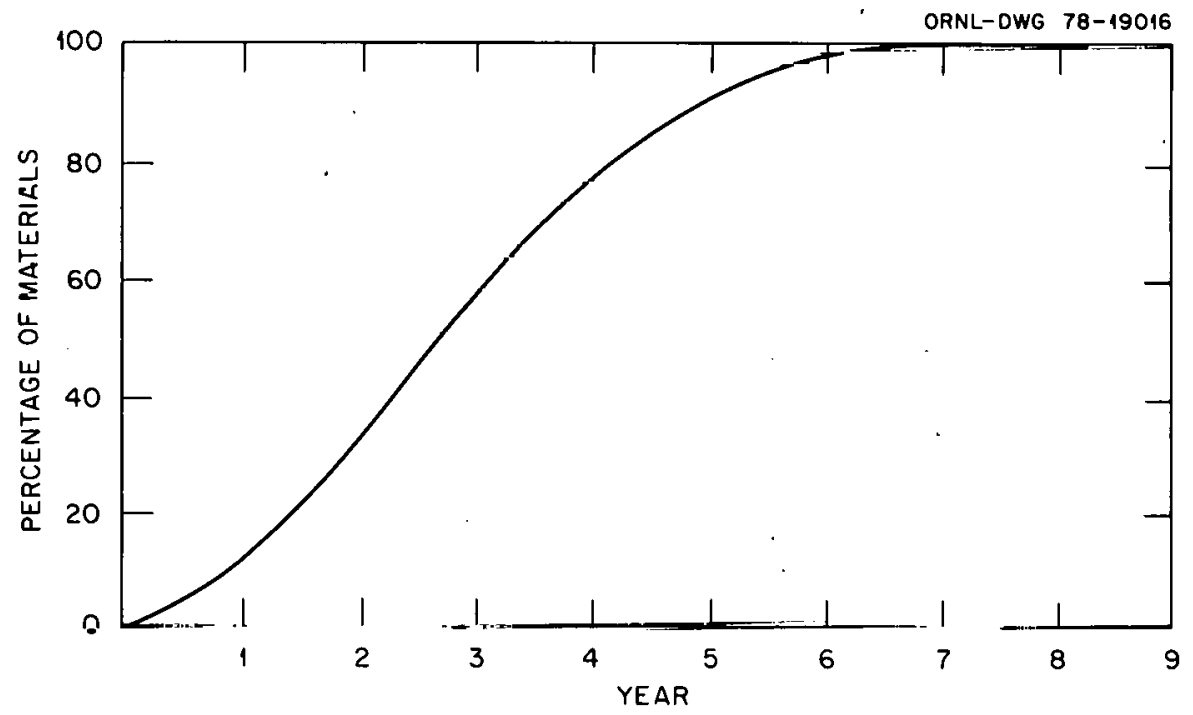

Fig. 3. Timé sequence of prócurement.

If one knows something of the labor component of the regional production represented in Table 10, the regional income and employment impacts of such production can be calculated. We have not looked into this point sufficiently to justify certain values of the necessary factors developed in Isard et al. (1976) for the Philadelphia region. The reader can modify our analysis as he or she sees fit.

In the Philadelphia study, after-tax wages accounted for about onethird of the value of regional production that was generated by the local purchase of construction materials. Dividing the year-by-year regional production figure of Table 10 by three thus yields a rough approximation of the regional income effects. These effects are indicated in Table 11. Going one step further, division of the regional income figures by the approximate after-tax annual income yields regional employment impacts. Because much locally purchased material is from high-skill industry (e.g., metal products), a reasonable rate to use for illustrative purposes is that of construction labor (i.e., $\$ 15,000$ after-tax annual income). The calculated employment impacts are indicated in column 3 of Table 11. Obviously, a much more detailed look at the composition of the regional product would provide better estimates of the relevant factors. 
Table 10. Regional production impact of local material purchases for the Hartsvilie nuclear power plant

\begin{tabular}{ccc}
\hline Year & $\begin{array}{c}\text { Percentage of total } \\
\text { local materials } \\
\text { supplied } a\end{array}$ & $\begin{array}{c}\text { Annual increase } \\
\text { in regional } \\
\text { product }\left(\$ 10^{3}\right)^{b}\end{array}$ \\
\hline 1 & 11 & 25,580 \\
2 & 22 & 51,160 \\
3 & 25 & 58,136 \\
4 & 20 & 46,509 \\
5 & 13 & 30,231 \\
6 & 7 & 16,278 \\
7 & 2 & 4,651 \\
9 & 0 & 0 \\
10 & 0 & 0 \\
& 0 & 232,545 \\
\hline & 100 & \\
a Based on Fig. 2. & \\
b & 0
\end{tabular}

Finally, the total impacts (direct, indirect, and induced) of the construction and operation of the Hartsville plant on the regional economy can be presented. In Table 11, the impacts following from labor inputs (Table 9) and those following from local material inputs (Table 10) were added to indicate the total regional economic impacts.

To put these figures in some perspective, consider them relative to existing levels of employment, income, and population in the study region. The peak construction labor force of 5100 workers is only $2 \%$ of the total civilian labor force in the study region. Considering the six counties individually, however, will probably reveal wide variations in this statistic. For example, using the weighting of Table 8 to arrive at an assumed distribution of the peak labor force over the six counties, the construction workers resident in each county as a percentage of total civilian work force in the county would be as follows:

\section{County}

Davidson

Macon

Smith

Sumner

Trousdale

Wilson

Total
Percentage of total civilian work force 
Table 11. Total regional econcric impact of the Hartsville nuclear power plant ${ }^{a}$

\begin{tabular}{|c|c|c|c|c|c|c|c|c|c|}
\hline \multirow[b]{2}{*}{ Year } & \multicolumn{3}{|c|}{ Employment impacts from: } & \multicolumn{3}{|c|}{ Income effects from: } & \multicolumn{3}{|c|}{ Regional production from: } \\
\hline & $\begin{array}{r}\text { Labor } \\
\text { inputs }\end{array}$ & $\begin{array}{c}\text { Local } \\
\text { material } \\
\text { purchases } \\
\text { (No. of jobs) }\end{array}$ & Total & $\begin{array}{l}\text { Labor } \\
\text { inputs }\end{array}$ & $\begin{array}{c}\text { Local } \\
\text { material } \\
\text { purchases } \\
\left(\$ 10^{6}\right)\end{array}$ & Total & $\begin{array}{l}\text { Labor } \\
\text { inputs }\end{array}$ & $\begin{array}{c}\text { Local } \\
\text { material } \\
\text { purchases } \\
\left(\$ 10^{6}\right)\end{array}$ & Total \\
\hline $\begin{array}{r}1 \\
2 \\
3 \\
4 \\
5 \\
6 \\
7 \\
8 \\
9 \\
10\end{array}$ & $\begin{array}{r}2,750 \\
8,000 \\
11,000 \\
12,875 \\
12,375 \\
9,500 \\
4,900 \\
2,150 \\
1,150 \\
1,150\end{array}$ & $\begin{array}{r}570 \\
1,140 \\
1,290 \\
1,030 \\
675 \\
360 \\
110 \\
0 \\
0 \\
0\end{array}$ & $\begin{array}{r}3,320 \\
9,140 \\
12,290 \\
13,905 \\
13,050 \\
9,860 \\
5,010 \\
2,150 \\
1,150 \\
1,150\end{array}$ & $\begin{array}{r}23.1 \\
83.1 \\
113.6 \\
132.7 \\
127.2 \\
98.2 \\
50.9 \\
21.7 \\
11.1 \\
11.1\end{array}$ & $\begin{array}{r}8.5 \\
17.1 \\
19.4 \\
15.5 \\
10.1 \\
5.4 \\
1.6 \\
0 \\
0 \\
0\end{array}$ & $\begin{array}{r}37.6 \\
100.2 \\
133.0 \\
148.2 \\
137.3 \\
103.6 \\
52.5 \\
21.7 \\
11.1 \\
11.1\end{array}$ & $\begin{array}{r}58.2 \\
166.2 \\
227.2 \\
265.4 \\
254.4 \\
196.4 \\
101.8 \\
43.4 \\
22.2 \\
22.2\end{array}$ & $\begin{array}{r}25.6 \\
51.2 \\
58.1 \\
46.5 \\
30.2 \\
16.3 \\
4.7 \\
0 \\
0 \\
0\end{array}$ & $\begin{array}{r}83.8 \\
217.4 \\
285.3 \\
311.9 \\
284.6 \\
212.7 \\
106.5 \\
43.4 \\
22.2 \\
22.2\end{array}$ \\
\hline
\end{tabular}

${ }^{a}$ This table is for illustrative purposes only. The information contained herein taken from Tables 9 and 10 was derived from we 17 -justified planning factors (columns 2, 5, and 9). 0ther figures here are for illustrative purfoses onily as explained in the text. (Estimates are given in 1975 dollars.) 
Additionally, considering all employment impacts at peak year (about $14,000)$, we see that the figure represents close to $6 \%$ of the civilian work force in the region. Because the work force of the plant is well paid relative to the mean income for the Hartsville region, however, the income impacts of the project at the year of peak labor will be somewhat greater; the total income of the labor force will be roughly 8 to 10\% of the total income of residents within the study area. This obviously represents significant impacts on the Hartsville-Nashville area, particularly if one considers the breakdown of these impacts by economic sector or geographic subregion (e.g., trade, hotels).

Finaliy, using the assumed rates of in-migration to the region given in Table 3 for the project and assuming a planning factor of 2.5 persons per household, about 4000 in-migrants to the region directly associated with the project can be expected at peak. The rate of inmigration for 1960 to 1970 amounts to about $20 \%$ of the actual net migration into the region over that period, again a significant level, even considering that the broad six-county study region includes most of the Nashville Standard Metropolitan Statistical Area (SMSA).

\section{CONCLUSIONS}

In this part of our research we dealt with regional economic impact. We discussed the use of a methodology and indicated how answers to different kinds of questions relating to economic impact can be obtained. The results are, of course, highly dependent on the assumptions that an analyst may wish to make. For example, from the assumption that $14 \%$ of material inputs for the 4800-MW Hartsville nuclear power plant would be purchased in the relevant six-county study region and that $86 \%$ would be imported, and from a host of other assumptions that we and others considered reasonable, we found that:

1. The number of new jobs might increase from 3320 in the first year construction begins to 13,905 in the fourth year and decline to 1150 in the ninth year, by which time all construction activity should bie concluded.

2. New income might increase from $\$ 37.6$ million in the first year to $\$ 148.2$ million in the fourth year and decline to $\$ 11.1$ million in the ninth year.

3. The increase in total dollar value of regional production might rise from $\$ 83.8$ million in the first year to $\$ 311.9$ million in the fourth year and decline to $\$ 22.2$ million in the ninth year.

The impact would be greatest in Trousdale County where we expect that resident construction workers could constitute $64 \%$ of the civilian work force in the peak year. All these magnitudes, however, may vary significantly under the many different sets of assumptions that can be examined with the flexible methodology presented. 
THIS PAGE

WAS INTENTIONALLY

LEFT BLANK 
Appendix A

\section{SUMMARY OF OTHER FINDINGS}

In the second area of our research, we developed a tool for studying changes in patterns of interactions among relevant organizations, institutions, and other social, political, and economic groups in a community or regional society. This tool is an interactions matrix. We indicated its quantitative character, how it might be constructed, and its ability to use the specific kinds of assumptions an investigator feels relevant to the community. We suggested how it could help deepen the analys is associated with the longitudinal survey data and current investigations relating to the Hartsville nuclear power plant and provide further understanding of attitude structures at different points in time and their changes over time. Although no such interactions matrix has as yet been constructed, we suggest that it is now possible to do so. Further, an array of diverse sets of interaction matrices can be constructed at relatively low cost. This is because the basic data for any one interactions matrix for any unit of time can be quickly processed at very low cost to yield the necessary data for other interaction matrices for the same unit of time. We therefore strongly urge that further research be conducted in this particular direction and are confident that the resulting magnitudes will be able to be effectively fused with the economic magnitudes generated by the methodology used in the first area of this research.

Finally, in the third area of our research we point out that effective impact assessment, as a task undertaken by public and other agencies, requires that standards be established. We have suggested that such standards are, in part, provided by higher levels of government and in part by interactions between individuals and among people working out their agendas in groups. In certain domains, the balance leans to the scientific (e.g., pollution control); in others, to the nonscientific (e.g., determination of the local share of labor force in a construction project).

Such a perspective suggests that standards are the result both of technical determination and of political processes. Therefore, it is important to consider ways in which a community can build up its decision-making capacity in this area. We label such its "responseability," or RA.

As is clearly recognized, change occasioned by, for example, major reactor construction, is anything but routine and thus places heavy demands on a decision-making unit. As such, RA declines initially. As others have, however, we hypothesize that decision-making skills (RA) are learned. Thus, there can be built up in a community a capability to confront not only the challenges and problems of reactor construction and impact but also other issues and problems such as local unemployment or environmental management. The building up of such capability can be understood in part with the use of interaction analysis.

It is currently very difficult to estimate the impact of major reactor construction on the development of this capability - which may 
well be considered a highly desirable outcome for a community - and to derive measurement indices of such a capability. Thus, this is a very fruitful area for further research and might well be judged worthy of financial support. 
Appendix B

\section{CALCULATION OF LOCAL PURCHASES FOR A NUCLEAR PLANT IN THE PHILADELPHIA REGION*}

Income, employment, and production will be generated by the demands for materials and equipment required to build the power plant. This is in addition to the impact generated by the wages paid to the work force engaged in the construction of a nuclear generating station. Considering a combination of these two impacts will give a total effect resulting from the construction of a 2-unit, 2400-MW nuclear power plant.

In the same way that construction-worker incomes were allocated to a final-demand (consumption) vector, it was also necessary to identify the quantities of materials required to construct these units. These quantities were then allocated to the appropriate final-demand sectors. ${ }^{\dagger}$

A number of considerations and modifications were required for this part of the analysis. Because of the unique characteristics of many material components, it was first necessary to identify those items that would not be produced in the Philadelphia region. In an input-output analysis this step typically requires the use of the matrix of trade coefficients. These coefficients modify the interindustry (endogenous) matrix to distinguish between local and nonlocal purchases. However, in the case of some very specialized materials, it is best to identify a priori those components that cannot be produced within the region and el iminate them from the final-demand vector before the calculation of the impacts. The reason for this is that, although the Philadelphia InputOutput Model is highly disaggregated and diversified, the level of disaggregation is not fine enough to pick up local production of very specialized individual items. And, because many of these highly specialized items appear as costly components, it was felt that these should be eliminated before making the calculations.

With the help of several informed staff members of the Public Service Electric \& Gas Company (PSE\&G), the following components were identified as items not produced by establishments in the Philadelphia area:

- Reactor vessels

- Control-rod drive systems

- Reactor coolant pumps

- Steam generators

- Pressurizers

- Compressors (waste gas)

- Drumming stations

- Major cranes

- Diesel genrators

*Taken from Isard et al. (1976).

${ }^{\dagger}$ Certain services, including some salaries, as part of the design and construction of the plant have been included in the materials category to be consistent with the accounting convention used in WASH-1230 (USAEC 1972). 
It was assumed that the technology, capacity, and skilled labor exist in the Philadelpha area to produce the remaining material inputs.* An assumption was made regarding the production of the remaining materials in the Philadelphia area. The fact that a regional economy can produce a given item does not necessarily imply that it will. Given that it may be closest geographically to the construction site, there exists an advantage in the cost of transporting the finished product. But for many of the products, the cost of transportation may be relatively minor compared with the total value. In these cases, the geographical advantage may be easily offset by other interregional costs. The producers of the materials are selected by competitive bidding. It is not unusual for, say, a Japanese firm to be awarded a contract for some highly specialized items. Likewise, firms located on the East Coast of the United States could be considered likely candidates to receive contracts for less highly speclalized goods. By assuming that all feasible materials would be produced in Philadelphia, we would overestimate the regional economic effects. The degree of overestimation will depend on site- and time-specific considerations. We therefore had to calculate the proportion likely to be produced regionally.

Estimates of material purchases for a 2-unit, 2400-MW nuclear generating station are presented in Table B.1. The estimates, initially based on cost estimates for materials and labor presented in WASH-1230, Vol. 1 (USAEC, 1972), are given in column 1 of Table B.1. They were derived for a 1000-MW unit with once-through cooling, were based on 1971 regulations, and are given in 1971 dollars. Given these conditions, the total material cost estimate was $\$ 114,410,000$.

A report [WASH-1345. (USAEC 1974)] published in 1974 modified the material cost estimate to account for changes in regulations between 1971 and 1974; these values are given (in 1971 dollars) in column 2 of Table B.1. Table B.2 presents the incremental material costs per WASH-1345 (IISAF.C 1974) [over and above the WASH-1230 (USAEC 1972) estimates] resulting from changes in U.S. Atomic Energy Commission regulations. Column 3 of lable B.I is the summation of the estimates of the first two columns, the result giving the material cost estimate for a 1000-MW reactor based on 1974 regulations and stated in 1971 dollars. This total is $\$ 137,957,000$.

To account for the differences in costs between a 1000- and a 1200-MW generating station, WASH-1345 (USAEC 1974) presented the following unit cost estimates:

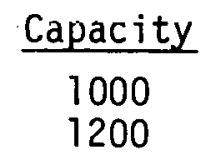

$\frac{\$ / \mathrm{kW}(\mathrm{e})}{598}$

\footnotetext{
*The input-output calculations made here are on the basis of FOB prices. As such, they fail to account for the cost of transportation from producers to the site, which can be high for some items. Transportation costs from producer to site are reflected indirectly, however, by the transport services sector (SIC 41). Personal transportation (inclusive of home-to-work trips) is part of the consumer expenditure.
} 
Table B.l. Calculation of material purchases within the Philadelphia region for a 2400-MW nuclear plant constructed within the region (All figures in thousands of dollars)

\begin{tabular}{|c|c|c|c|c|c|c|c|}
\hline \multirow[b]{2}{*}{$\begin{array}{l}\text { SIC } \\
\text { sector } \\
\text { code }\end{array}$} & \multirow[b]{2}{*}{$\begin{array}{c}\text { WASH- } 1230 \\
(1000 \mathrm{MW}) \\
\text { (1) }\end{array}$} & \multirow[b]{2}{*}{$\begin{array}{c}\text { WASH- } 1345 \\
\text { additions } \\
(1000 \mathrm{MW}) \\
\text { (2) }\end{array}$} & \multirow[b]{2}{*}{$\begin{array}{c}\text { Col. } 1+ \\
\text { col. } 2^{2} \\
(1000 \mathrm{MW}) \\
(3)\end{array}$} & \multirow[b]{2}{*}{$\begin{array}{c}\text { Unit } 1 \\
\text { cost }= \\
\text { col } 3 x \\
1.13 \\
(1200 \mathrm{MW}) \\
(4)\end{array}$} & \multirow[b]{2}{*}{$\begin{array}{c}\text { Unit } 2 \\
\text { costa } \\
(1200 \mathrm{MW}) \\
(5)\end{array}$} & \multicolumn{2}{|c|}{ Two-unit total } \\
\hline & & & & & & $\begin{array}{c}\text { Col. } 4+ \\
\text { col. } 5 \\
(2400 \mathrm{MW}) \\
(1971 \$) \\
(6)\end{array}$ & $\begin{array}{c}\text { Col. } 6 \times \\
1.48 \\
(2400 \mathrm{MW}) \\
(1975 \$) \\
(7)\end{array}$ \\
\hline $\begin{array}{l}1611 \\
1621 \\
1711 \\
1731 \\
2421\end{array}$ & $\begin{array}{r}136 \\
3,187 \\
2 \\
36 \\
73\end{array}$ & $\begin{array}{r}1,159 \\
1 \\
10 \\
-\quad 29\end{array}$ & $\begin{array}{r}136 \\
4,346 \\
. \quad 3 \\
46 \\
102\end{array}$ & $\begin{array}{r}154 \\
4,911 \\
3 \\
52 \\
115\end{array}$ & $\begin{array}{r}1,999 \\
3 \\
35 \\
64\end{array}$ & $\begin{array}{r}154 \\
6,910 \\
6 \\
88 \\
179\end{array}$ & $\begin{array}{r}227 \\
10,226 \\
8 \\
130 \\
. \quad 265\end{array}$ \\
\hline $\begin{array}{l}2433 \\
2522 \\
2542 \\
2599 \\
2540\end{array}$ & $\begin{array}{r}8 \\
80 \\
80 \\
125 \\
30\end{array}$ & 2 & $\begin{array}{r}10 \\
50 \\
80 \\
125 \\
38\end{array}$ & $\begin{array}{r}11 \\
57 \\
90 \\
141 \\
43\end{array}$ & 5 & $\begin{array}{r}11 \\
57 \\
95 \\
141 \\
43\end{array}$ & $\begin{array}{r}17 \\
84 \\
140 \\
209 \\
64\end{array}$ \\
\hline $\begin{array}{l}2843 \\
2851 \\
2952 \\
2992 \\
3251\end{array}$ & $\begin{array}{r}65 \\
110 \\
207 \\
25 \\
10\end{array}$ & $\begin{array}{r}2 \\
2 \\
22 \\
3\end{array}$ & $\begin{array}{r}67 \\
113 \\
233 \\
25 \\
13\end{array}$ & $\begin{array}{r}76 \\
127 \\
263 \\
28 \\
14\end{array}$ & $\begin{array}{r}36 \\
121 \\
189 \\
28\end{array}$ & $\begin{array}{r}112 \\
249 \\
452 \\
57 \\
14\end{array}$ & $\begin{array}{r}166 \\
368 \\
669 \\
84 \\
21\end{array}$ \\
\hline $\begin{array}{l}3253 \\
3271 \\
3272 \\
3273 \\
3291\end{array}$ & $\begin{array}{r}1 \\
25 \\
153 \\
1,987 \\
2\end{array}$ & $\begin{array}{r}8 \\
2 \\
372\end{array}$ & $\begin{array}{r}1 \\
33 \\
155 \\
2,359 \\
2\end{array}$ & $\begin{array}{r}1 \\
37 \\
175 \\
2,665 \\
2\end{array}$ & $\begin{array}{r}23 \\
2,189\end{array}$ & $\begin{array}{r}1 \\
59 \\
175 \\
4,854 \\
2\end{array}$ & $\begin{array}{r}1 \\
88 \\
259 \\
7,185 \\
4\end{array}$ \\
\hline $\begin{array}{l}3292 \\
3312 \\
3321 \\
3357 \\
3432\end{array}$ & $\begin{array}{r}597 \\
310 \\
25 \\
1,445 \\
176\end{array}$ & $\begin{array}{r}717 \\
173 \\
2,159 \\
7\end{array}$ & $\begin{array}{r}1,313 \\
483 \\
25 \\
3,604 \\
183\end{array}$ & $\begin{array}{r}1,484 \\
546 \\
28 \\
4,073 \\
206\end{array}$ & $\begin{array}{r}1,480 \\
113 \\
17 \\
3,857 \\
99\end{array}$ & $\begin{array}{r}2,964 \\
659 \\
45 \\
7,929 \\
305\end{array}$ & $\begin{array}{r}4,387 \\
975 \\
67 \\
11,735 \\
451\end{array}$ \\
\hline $\begin{array}{l}3441 \\
3442 \\
3443 \\
3444 \\
3449\end{array}$ & $\begin{array}{r}3,344 \\
129 \\
5,485 \\
895 \\
1,931\end{array}$ & $\begin{array}{r}1,157 \\
11 \\
2,930 \\
175 \\
155\end{array}$ & $\begin{array}{r}4,501 \\
140 \\
8,416 \\
1,070 \\
2,085\end{array}$ & $\begin{array}{r}5,086 \\
159 \\
9,510 \\
1,209 \\
2,357\end{array}$ & $\begin{array}{r}4,718 \\
150 \\
9,418 \\
910 \\
2,133\end{array}$ & $\begin{array}{r}9,804 \\
308 \\
18,928 \\
2,119 \\
4,489\end{array}$ & $\begin{array}{r}14,510 \\
457 \\
28,013 \\
3,136 \\
6,644\end{array}$ \\
\hline $\begin{array}{l}3452 \\
3481 \\
3494 \\
3496 \\
3498\end{array}$ & $\begin{array}{r}121 \\
16 \\
9,914 \\
.311 \\
1,005\end{array}$ & $\begin{array}{r}2 \\
4,221 \\
143 \\
531\end{array}$ & $\begin{array}{r}123 \\
16 \\
14,134 \\
455 \\
1,536\end{array}$ & $\begin{array}{r}139 \\
18 \\
15,972 \\
514 \\
1,735\end{array}$ & $\begin{array}{r}139 \\
15,250 \\
510 \\
1,735\end{array}$ & $\begin{array}{r}279 \\
18 \\
31,222 \\
1,024 \\
3,471\end{array}$ & $\begin{array}{r}413 \\
27 \\
46,208 \\
1,515 \\
5,137\end{array}$ \\
\hline $\begin{array}{l}3499 \\
3510 \\
3531 \\
3534 \\
3536\end{array}$ & $\begin{array}{r}1,246 \\
30,168 \\
6,035 \\
50 \\
45\end{array}$ & $\begin{array}{r}159 \\
2 \\
4 \\
3\end{array}$ & $\begin{array}{r}1,405 \\
30,170 \\
6,035 \\
54 \\
48\end{array}$ & $\begin{array}{r}1,588 \\
34,092 \\
6,820 \\
61 \\
54\end{array}$ & $\begin{array}{r}1,274 \\
34,092 \\
6,820 \\
61 \\
54\end{array}$ & $\begin{array}{r}2,862 \\
68,183 \\
13,693 \\
121 \\
108\end{array}$ & $\begin{array}{r}4,235 \\
100,911 \\
20,186 \\
179 \\
159\end{array}$ \\
\hline $\begin{array}{l}3559 \\
3561 \\
3564 \\
3567 \\
3569\end{array}$ & $\begin{array}{r}9,578 \\
826 \\
962 \\
48 \\
88\end{array}$ & $\begin{array}{r}3,117 \\
397 \\
233 \\
6 \\
47\end{array}$ & $\begin{array}{r}12,714 \\
1,223 \\
1,195 \\
53 \\
135\end{array}$ & $\begin{array}{r}14,367 \\
1,382 \\
1,350 \\
60 \\
152\end{array}$ & $\begin{array}{r}14,264 \\
1,300 \\
1,313 \\
37 \\
126\end{array}$ & $\begin{array}{r}28,632 \\
2,682 \\
2,663 \\
97 \\
278\end{array}$ & $\begin{array}{r}42,375 \\
3,970 \\
3,941 \\
144 \\
411\end{array}$ \\
\hline $\begin{array}{l}3573 \\
3585 \\
3612 \\
3613 \\
3621\end{array}$ & $\begin{array}{r}1,585 \\
275 \\
729 \\
706 \\
1,012\end{array}$ & 27 & $\begin{array}{r}1,585 \\
284 \\
729 \\
706 \\
1,039\end{array}$ & $\begin{array}{r}1,791 \\
321 \\
824 \\
797 \\
1,174\end{array}$ & $\begin{array}{r}824 \\
797 \\
1,174\end{array}$ & $\begin{array}{r}1,791 \\
321 \\
1,648 \\
1,594 \\
2,347\end{array}$ & $\begin{array}{r}2,650 \\
475 \\
2,439 \\
2,360 \\
3,474\end{array}$ \\
\hline
\end{tabular}


Table B.1 (continued)

\begin{tabular}{|c|c|c|c|c|c|c|c|}
\hline \multirow[b]{2}{*}{$\begin{array}{l}\text { SIC } \\
\text { sector } \\
\text { code }\end{array}$} & \multirow[b]{2}{*}{$\begin{array}{c}\text { WASH- } 1230 \\
(1000 \mathrm{MW}) \\
(1)\end{array}$} & \multirow[b]{2}{*}{$\begin{array}{c}\text { WASH- } 1345 \\
\text { add it ions } \\
(1000 \mathrm{MW}) \\
(2)\end{array}$} & \multirow[b]{2}{*}{$\begin{array}{c}\text { Col. } 1+ \\
\text { col. } 2 \\
(1000 \text { MW }) \\
(3)\end{array}$} & \multirow[b]{2}{*}{$\begin{array}{c}\text { Unit } 1 \\
\operatorname{cost}= \\
\operatorname{col} 3^{3 x} \\
1.13 \\
(1200 \mathrm{MW}) \\
(4)\end{array}$} & \multirow[b]{2}{*}{$\begin{array}{c}\text { Unit } 2 \\
\operatorname{costa} \\
(1200 \mathrm{MW}) \\
(5)\end{array}$} & \multicolumn{2}{|c|}{ Two-unit total } \\
\hline & & & & & & $\begin{array}{c}\text { Col. } 4+ \\
\text { col. } 5 \\
(2400 \mathrm{MW}) \\
(1971 \text { \$) } \\
(6)\end{array}$ & $\begin{array}{c}\mathrm{Co} .6 \mathrm{x} \\
1.48 \\
(2400 \mathrm{MW}) \\
(1975 \$) \\
(7)\end{array}$ \\
\hline $\begin{array}{l}3622 \\
3623 \\
3629 \\
3642 \\
3643\end{array}$ & $\begin{array}{r}1,723 \\
390 \\
10 \\
80 \\
575\end{array}$ & 1,149 & $\begin{array}{r}2,872 \\
390 \\
10 \\
80 \\
575\end{array}$ & $\begin{array}{r}3,245 \\
441 \\
11 \\
90 \\
650\end{array}$ & $\begin{array}{r}3,118 \\
441 \\
11 \\
6 \\
650\end{array}$ & $\begin{array}{r}6,363 \\
881 \\
23 \\
96 \\
1,300\end{array}$ & $\begin{array}{r}9,418 \\
1,304 \\
33 \\
142 \\
1,924\end{array}$ \\
\hline $\begin{array}{l}3644 \\
3661 \\
3690 \\
3011 \\
3821\end{array}$ & $\begin{array}{r}305 \\
35 \\
131 \\
45 \\
6\end{array}$ & $\begin{array}{r}940 \\
202 \\
3,227 \\
25\end{array}$ & $\begin{array}{r}1,245 \\
35 \\
333 \\
3,272 \\
31\end{array}$ & $\begin{array}{r}1,407 \\
40 \\
376 \\
3,697 \\
35\end{array}$ & $\begin{array}{r}1,407 \\
00 \\
370 \\
35\end{array}$ & $\begin{array}{r}2,814 \\
40 \\
746 \\
3,697 \\
70\end{array}$ & $\begin{array}{r}4,164 \\
59 \\
1,104 \\
5,472 \\
103\end{array}$ \\
\hline $\begin{array}{l}3999 \\
7301\end{array}$ & $\begin{array}{r}10 \\
25,715 \\
\end{array}$ & & $\begin{array}{r}10 \\
25,715 \\
\end{array}$ & $\begin{array}{r}11 \\
29,058 \\
\end{array}$ & $\begin{array}{r}11 \\
15,667 \\
\end{array}$ & $\begin{array}{r}23 \\
44,725 \\
\end{array}$ & $\begin{array}{r}33 \\
66,194 \\
\end{array}$ \\
\hline $\begin{array}{c}\text { Regional } \\
\text { total }\end{array}$ & 114,410 & 23,547 & 137,957 & 155,896 & 129,070 & 284,966 & 421,750 \\
\hline \multicolumn{4}{|c|}{ Material purchased outside region } & & & & 119,154 \\
\hline \multicolumn{3}{|c|}{ Total material } & & & & & 540,904 \\
\hline
\end{tabular}

$a_{\text {WASH-1345 (USAEC 1974) economies of scale reflected. }}$ 
Table B.2. Increased material costs due to WASH-1345 regulations

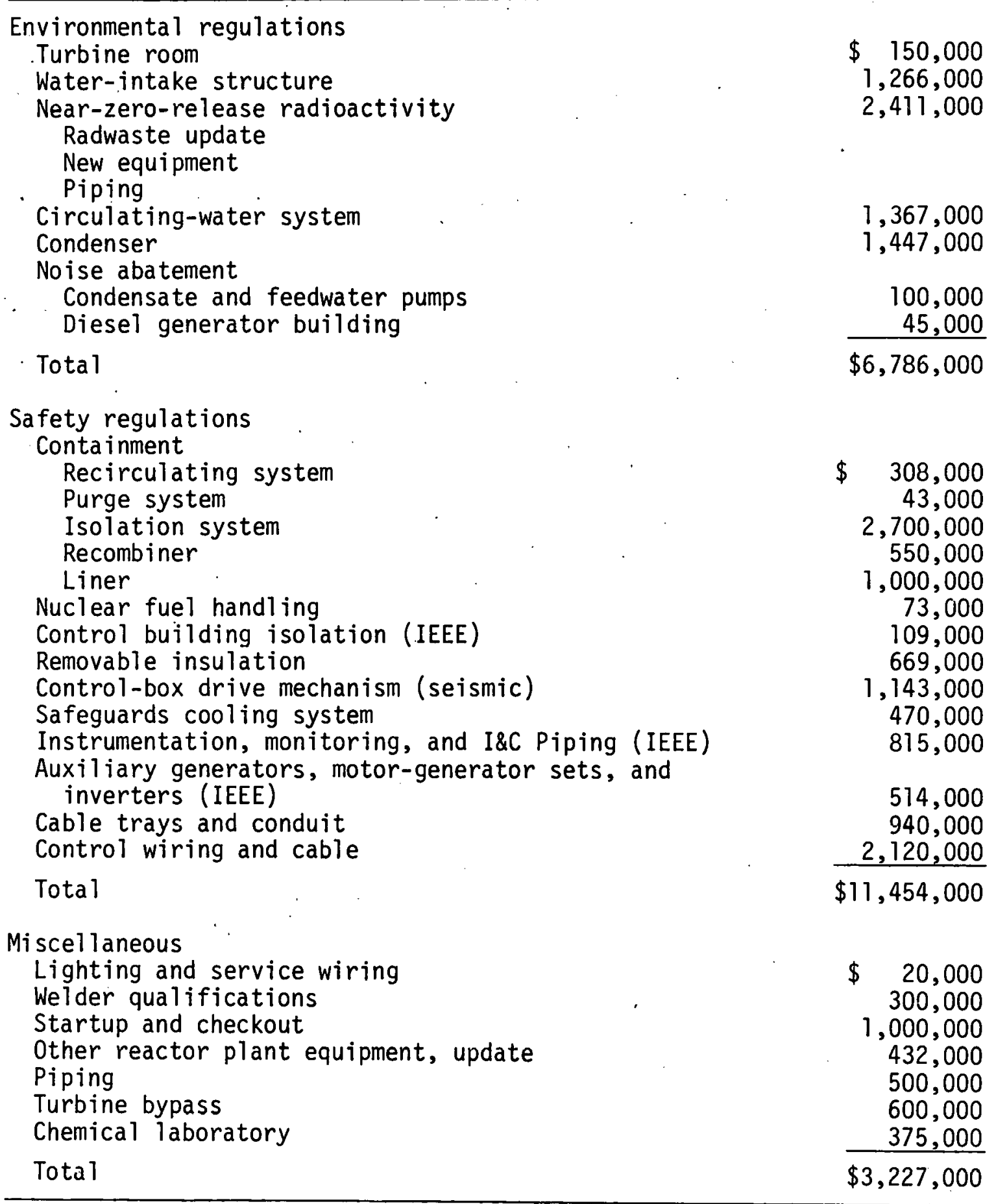


Thus, we can determine that by increasing the capacity by $20 \%$ the total cost of construction will increase by only $13 \%$. As a result, the estimates given in column 3 of Table B. 1 were adjusted to taken into account the change in capacity.* The values given in column 4 then are the estimated costs of the material used in the construction of a single 1200-MW unit which would potentially be produced in the Philadelphia area. These are also given in 1971 dollars.

Construction of the second unit would involve significant economies of scale. A number of the facilities constructed for the first unit would not have to be duplicated for the second. As given by WASH-1345 (USAEC 1974); these include the following.

1. Most of the site-preparation costs are covered during the construction of the first unit.

2. Roads and railroad spurs and sidings would not have to be duplicated, thus eliminating those costs from estimates for the second unit.

3. Engineering and architectural costs are covered almost totally for construction of the first unit; this would include the preparation of the environmental impact study, the licensing process, design analysis, etc.

4. The need for only one main administration building, the costs of which were estimated for the first unit.

5. Only one of each of the following would be required:

a. Cooling-water-discharge facilities

b. Warehouses

c. Control-room areas

d. Laboratory facilities

e. rences, guardhouses

f. Radiation-monitoring systems

g. Radioactive-waste-disposal facility

h. Fuel handling and storage tacility

i. Computer equipment

The elimination of these components for the second unit (USAEC 1972, Appendix) is estimated to reduce the construction costs for that unit by 10 to $15 \%$. When we compare the bill of goods estimated to be produced in the Philadelphia area (comparing column 4 with 5, Table B.1), we see that the reduced material cost amounts to about $17 \%$. By adding columns 4 and 5 (resulting in column 6), we derive the estimates of the material produced in the Philadelphia area that would be used in the construction of a 2-unit, 2400-MW nuclear generating station.

These values were then proportionately adjusted to reflect present (1975) prices, and the results are given in column 7 . These figures are thus estimates of the materials produced in the Philadelphia area for a 2-unit, 2400-MW generating station, in terms of 1974 regulations and 1975 prices.

* We have used an across-the-boards factor of $13 \%$. With more time and resources, item-by-item adjustments could be made. 
Some of the highest cost items given in column 7 are:

$\begin{array}{llr}\text { Heavy construction } & \text { (SIC 1621) } & \$ 10,226,000 \\ \text { Ready-mixed cement } & \text { (SIC 3273) } & 7,185,000 \\ \text { Nonferrous wire } & \text { (SIC 3357) } & 11,735,000 \\ \text { Fabricated structural steel } & \text { (SIC 3441) } & 14,510,000 \\ \text { Fabricated plate work } & \text { (SIC 3443) } & 28,013,000 \\ \text { Valve and pipefitting } & \text { (SIC 3494) } & 46,208,000 \\ \text { Turbines, etc. } & \text { (SIC 3510) } & 100,911,000 \\ \text { Construction machinery } & \text { (SIC 3531) } & 20,186,000 \\ \text { Special industrial machinery } & \text { (SIC 3559) } & 42,375,000 \\ \text { Industrial controls } & \text { (SIC 3622) } & 9,418,000 \\ \text { Business services } & \text { (SIC 7301) } & 66,194,000\end{array}$

Costs calculated for the material assumed to be produced in other than the Philadelphia area amounted to $\$ 119,154,000$, making the estimate for the total material cost, irrespective of the source of production, $\$ 540,904,000$.

All costs are in terms of FOB prices, so additional costs (capacity and labor input) would be incurred in transporting the material to the site. Because transportation costs would be very site specific with respect to the nuclear power plant site and location of production, the costs would vary widely. Because of this, they were not considered in the input-output calculation of impacts. 
THIS PAGE

WAS INTENTIONALLY

\section{LEFT BLANK}




\section{BIBL IOGRAPHY}

Baumol, W. J., and Oates, W. E. 1975. The theory of environmental policy. Englewood Cliffs, N. J.: Prentice Hall.

Breese, G. W. 1965. The impact of large installations on nearby areas. Port Hueneme, Calif.: U.S. Naval Civil Engineering Laboratory.

Hirsch, W. Z. 1973. Urban economic analysis. New York: McGraw-Hill.

Isard, W. 1960. Methods of regional analysis. Massachusetts Institute of Technology, Cambridge, Mass.: MIT Press.

Isard, W., and Deutsch, K. W. 1961. A note on a generalized concept of effective distance. Behav. Sci. 6 (October).

Isard, W., and Kuenne, R. E. 1953. The impact of steel upon the greater New York-Philadelphia industrial region. Rev. Econ. Statist. 35 (November).

Isard, W. and Langford, T. E. 1969. Impact of Viet Nom War on the Philadelphia economy. Discussion Paper 29. Philadelphia: Regional Science Research Institute.

- 1971. Regional input-output study. Cambridge, Mass.: MIT Press.

- 1968-1973. Working papers: the Philadelphia input-output study. Philadelphia: Regional Science Research Institute.

Isard, W., Reiner, T. A., and Van Zele, R. 1976. Regional economic impacts of nuclear power plants. BNL-50562. Upton, N.Y.: Brookhaven National Lahoratory.

Isard, W., et al. 1969. General theory: social, political, economic and regional. Cambridge, Mass.: MIT Press.

- 1975. Regional economic impacts of nuclear energy centers. Philadelphia: University of Pennsylvania.

Leven, C. L., et al. 1970. An analytic framework for regional development policy. Cambridge, Mass.: MIT Press.

Miernyk, W. H. 1965. The elements of input-output analysis. New York. Random House.

Moore, F. T. 1955. Regional economic reaction paths. Am. Econ. Rev. 45 (May).

Moore, F. T., and Perersen, J. W. 1955. Regional analysis: an interindustry model of Utah. Rev. Econ. Statist. 37 (November). 
Nourse, H. O. 1968. Regional economics. New York: McGraw-Hill.

Putnam, S. H. 1971. The effect of changing transport facilities on regional economic development: a case study of causal analysis. Pap. Reg. Sci. Assoc. 27: 151-166.

Reiner, T. A. 1971. A multiple goals framework for regional planning. Pap. Reg. Sci. Assoc. 26: 207-239.

- Forthcoming. Standards for social impact assessment. In Social systems, regional studies, regional policy, eds. 0 . Kulhalahti et al. Tampere, Finland: University of Tampere Press.

Richardson, H. W. 1972. Input-output and regional economics. New York: Wiley.

Shurcliff, A. 1977. The local economic impact of nuclear power. Technol. Rev. 79: 40-47.

Stenehjem, E. J., and Metzger, J. E. 1976. A fromework for projersting employment and population change accompanying energy development (draft). Argonne, Ill.: Argonne National Laboratory.

Sundstrom, E. D., et a1. 1977. Citizens' veiws about the proposed Hartsvilie nuclear power plant: a survey of residents' perceptions in August 1975. ORNL/TM-5801. Oak Ridge, Tenn.: Oak Ridge National Laboratory.

Tennessee Valley Authority. 1977. Hartsvizle nuclear plant's socioeconomic monitoring and mitigation report. Septembor 30, 1876. Knoxville, Tenn.: TVA.

Tiebout, C. M. 1962. The community economic base study. Supplementary Paper 16. Washington, D.C.: Committee for Economic Development.

U.S. Atomic Energy Commission. 1972. 1000-MW central station power plants investment cost study: Volume 1, pressurized water reactor plant. WASH-1230. Washington, D.C.: U.S. Government Printing Office.

U.S. Atomic Energy Commission. 1974. Power plant capital costs: current trends and sensitivity to economic parometers. WASH-1345. Washington, D.C.: U.S. Government Printing Dffice.

U.S. Bureau of the Census. 1973. Census of manufactures, 1972. Washington, D.C.: U.S. Government Printing Office.

U.S. Bureau of Labor Statistics. 1972. Industry wage survey: contract construction. Bulletin 1853. Washington, D.C.: U.S. Government Printing Office. 
U.S. Bureau of Labor Statistics. 1975. Handbook of Zabor statistics 1975. Reference edition. Bulletin 1865. Washington, D.C.: U.S. Government Printing Office.

U.S. Nuclear Regulatory Commission. 1975. Final environmental statement related to construction of Hartsville nuclear plants of the Tennessee Valley Authority. NUREG-75/039. Washington, D.C.: U.S. Government Printing Office. 
THIS PAGE

WAS INTENTIONALLY

LEFT BLANK 


\section{INTERNAL DISTRIBUTION}

1. H. G. Arnold

2. S. I. Auerbach

3. S. E. Beall, Jr.

4. D. J. Bjornstad

5. F. D. Boercker

6. C. R. Boston

7. B. H. Bronfman

8. A. A. Brooks

9. R. L. Burgess

10. C. C. Burwel1

11. R. S. Carlsmith

12. C. V. Chester

13. R. M. Davis

14. R. C. Devault

15. P. R. Fritts

16. W. Fulkerson

17. R. B. Honea

18. D. Jared

19. S. V. Kaye

20. C. R. Kerley

21. A. S. Loebl

22. H. A. McLain
23. J. W. Michel

24. W. R. Mixon

25. D. C. Parzyck

26. E. Peelle

27. H. Postma

28. C. R. Richmond

29. B. R. Rodgers

30. M. W. Rosenthal

31. T. H. Row

32-56. J. W. Sims

57. E. G. Struxness

58. T. Takayama

59. T. J. Wilbanks

60. D. J. Wilkes

61. H. E. Zittel

62-63. Central Research Library

64. Document Reference Section

65. Institute for Energy Analysis, ORAU

66. Laboratory Records (RC)

67-71. Laboratory Records Dept.

72. ORNL Patent Office

\section{EXTERNAL DISTRIBUTION}

73. Thomas A. Reiner, Department of Peace Science, University of Pennsylvania, McNeil Building CR, Philadelphia, Pennsylvania 19174.

74. Roger VanZele, Department of Peace Science, University of Pennsylvania, McNeil Building CR, Philadelphia, Pennsylvania 19174.

75-275. Energy Division, Regional and Urban Studies Distribution.

276-302. Technical Information Center, Department of Energy, P. 0. Box 62, Oak Ridge, Tennessee 37830.

303. Office of Assistant Manager, Energy Research \& Development, DOE-ORO 